\section{Оксана Микитенко}

Національна академія наук України

Інститут мистецтвознавства, фольклористики та етнології ім. М.Т. Рильського

Відділ української та зарубіжної фольклористики oksana_mykytenko@hotmail.com
УДК 811.163:393.94(497.11)

https://doi.org/10.18485/slavistika.2021.25.1.11

Оригинални научни рад примљено 19.05.2021.

прихваћено за штампу 17.06.2021.

\title{
ПОХОВАЛЬНІ ПЛАЧІ В ІНТЕРФЕРНТНИХ ЗОНАХ СЕРБІЇ: ДО ПРОБЛЕМИ ЕТНОКУЛЬТУРИ ПОРУБІЖЖЯ
}

У статті розглянуто лінгвістичні та екстралінгвістичні особливості традиції поховальної обрядовості в інтерферентних зонах Сербії, позначених процесами етнокультурних контактів. Виходячи із положень етнолінгвістичного аналізу, виокремлюються етнофольклорні діалекти, що демонструють певні локально-територіальні риси традиції (північний та південний варіанти; північно- та південно-східний, а також західно-сербський варіант), які відповідають мовно-культурному членуванню південнослов'янського діалектного простору.

Ключові слова: Сербія, поховальний текст, інтерферентна зона, фольклористика, етнокультурні контакти.

The paper discusses the linguistic and extralinguistic peculiarities of the funeral ritual tradition in the interference zones in Serbia marked with the processes of ethno-cultural contacts. Proceed from the principles of ethnolinguistic analysis the ethnofolklore dialects characterized by certain localterritorial traditional features are revealed (northern and southern variants; north- and southeast, as well as the western Serbian variant), conforming to the linguistic and cultural division of the South Slavic dialectal space.

Keywords: Serbia, funeral text, interference zone, folklore studies, ethno-cultural contacts.

У межах проблематики етнокультури порубіжжя серед основних напрямів аналізу можна виокремити вивчення процесів культурно-мовних контактів та явищ етнофольклорної інтерференції, зумовлених станом неоднорідності комунікативної спільноти у певних локальних традиціях або окремих регіонах. Водночас поняття культурного та мовного контакту тісно пов'язане із поняттям кордону. Складовими цього поняття є три взаємозумовлені елементи: географічний, або територіальний, а також мовний та культурний (Непоп 2004: 5). Кордон, за визначенням лінгвістів, - це явище передусім культурного характеру, де стикаються елементи настільки відмінні між собою, що вони сприймаються як чужі. Пропонуючи розмежовувати поняття зовнішнього та внутрішнього кордону, науковці залучають синонімічні терміни - пограниччя, або порубіжжя, які знаходять свій прояв також на рівні категоріального апарату.

Про складність поняття, зокрема і у європейській традиції культурної антропології, свідчить наявність цілої низки термінів (boundary, border, frontier), які враховують символічні, культурні, географічні, політичні, антропологічні та ін. аспекти дослідження (Thomassen 1996; Vereni 1996). П. Верені вважає найбільш антропологічно релевантним і таким, що містить етнічне значення «межі» (ethnic boundary), саме концепт 'frontier', який втілює історико-куль- 
турний сенс та пов'язує відношення особи, індивіда та ідентичністі (Vereni 1996: 82). Б. Томассен пропонує розмежовувати терміни і розуміє під терміном 'boundary' - 'межу', натомість під 'border', або 'borderland' - певну «зону», де «етнічні та національні ідентичності стикаються, виявляються, формуються та змінюються», тому саме «зона» мусить, на його переконання, бути предметом антропологічного вивчення (Thomassen 1996: 37-39). Значення кордону визначається тим, наголошує автор, що саме «завдяки певній території ми кажемо, хто ми є», прикладом чого можуть бути, зокрема, намагання німецької меншини у Данії, яка «економічні прагнення пов’язує з тим, аби кордони зникли, проте духовно їх усіляко підкреслює» (Jensen et al. 1974: 35).

Про мовно-культурний кордон переважно йдеться стосовно ізольованих спільнот (т.зв. «мовні острови»), водночас у більшості ситуацій наявні мовні та культурні контакти, відтак інтерференція є чинником мовного та культурного пограниччя / порубіжжя. Проблема мовно-культурної інтерференції є надзвичайно актуальною - ій приділено достатньо уваги в лінгвістичних, етнокультурних, фольклористичних дослідженнях. Упроваджений у науковий обіг У. Вайнрайхом термін мовної інтерференції (Вайнрайх 1979) залучається етнологами і фольклористами на позначення різних типів етнокультурної взаємодії, при цьому впливу можуть зазнавати обидві контактуючі культури. Це положення цілком відповідає спостереженням лінгвістів, які визначають інтерференцію як «процес взаємодії систем та елементів цих систем у мовах, що контактують» (Семчинський 1974: 31), а також «проникнення іншомовного елемента до мовлення сприймаючої мови», у чому полягає «один із типів мовної взаємодії» (Лазаренко 2001: 47).

Подібно до мовного, дослідження етнокультурного діалекту є одним із пріоритетних завдань сучасної етнолінгвістики, яка наголошує, що «народна культура є не менш діалектною і яскравою рисою етносу і етнічних утворень, ніж мова» (Толстой 1995: 29). Методи етнолінгвістики чимдалі активніше залучаються до фольклористичного аналізу. До проблем розробки діалектології культури слов'ян неодноразово звертався О. М. Трубачов, вважаючи, що цій темі у славістиці було приділено надзвичайно мало уваги (Трубачев 2003). Комплексний етнолінгвістичний підхід, за яким мова i культура $є$ явищами корелятивними, передбачає визначення діалекту у широкому сенсі слова: «Діалект (також макро- і мікродіалект) становить не виключно лінгвістичну територіальну одиницю, але водночас i етнографічну, i культурологічну» (Толстой 1995: 21). На території сучасної Славії діалектність етнокультурного простору і традиційної культури представлено цілою низкою варіантів у різних регіонах, зокрема і на території Сербії.

Етнічна мозаїчність південнослов'янського регіону, де дистантні явища майже не фіксуються, знаходить вияв у традиції поховального оплакування. Як архаїчна зона поясу старобалканської культури з досить яскраво визначеною інтерференцією слов'янської і романської мовної і фольклорно-етнографічної культури виділяються Банат та Північно-Східна Сербія (область Хомоля та Верхньої Ресави, а саме на північ від лінії Парачин - Заєчар), де оплакування померлих, тісно пов'язане із загальною традицією духовної культури регіону, представлено речитативним, монотонним, протяжним співом, підпорядкованим 
функціональній обрядовій домінанті. Загальні типологічні риси жанру 3 певними особливостями локального музично-фольклорного діалекту фіксуються в південно-східному регіоні Сербії, зокрема у локальній зоні Запланє між Нишем, Власотинцем і Білою Паланкою, що визначається як окремий музичнофольклорний ідіом Південно-Східної Сербії (Радиновић 1997: 442). Як свідчать спостереження, плачі цього регіону за своїми характеристиками - мелодичним та поетичним оформленням, інтонаційною нестабільністю, формальною структурою та вільною будовою вірша, орнаментикою тощо - найбільше тяжіють до традиції оплакування в середньо-західному регіоні Болгарії, що є одним із переконливих свідчень автохтонності цього регіону (Вукичевић-Закић 1997: 169).

Термінологія плачів у Банаті передає вокальну (запевка, жалопојка, кукање) і вербальну (нарицаљка, нарицање, набрајање) сторони тексту; про оплакування тут кажуть запевати, тужити, нарицати, ређати, набрајати; виконавиць називають нарикаче, запеваље тощо. У більшості місць Срему оплакування майже не побутує: «... кад неко умре... у Србији наричу, а у Срему само говоре...» (Fracile 1987: 35). Натомість у східній Сербії найдавнішим термінологічним визначенням оплакування вважається завијање / извијање; також кажуть плакање, кукање, вијење (останній термін зустрічається переважно в селах, що належать до південноморавського регіону).

Перевага наративних або вокально-музичних рис $\epsilon$ чинником розрізнення типологічних різновидів обрядового оплакування, яке побутує в сербів Воєводини - набрајаъе, що звучить переважно вдома і $\epsilon$ «розмовою» 3 покійним, та запевағе як спонтанний вираз жалю, переважно на цвинтарі, що супроводжується схлипуванням і сльозами, емоційними вигуками тощо, маючи певний інтонаційно-мелодійний малюнок.

У межах загальних регіональних функціонально-структурних характеристик досить відчутними $є$ інтонаційні й ритмо-метричні особливості плачів, водночас семантична спрямованість текстів, як ізофункціональна обрядовій сфері і пов'язана з уявленнями про посмертне існування, $\epsilon$ цілісною.

Серед ритуальних актів, що характеризують магічну спрямованість традиції північно-східного регіону, численними є дії з використанням асоціативної заміни-символу, котрі покликані захистити живих (особливо народжених в один день або місяць з померлим), аж до діалогічного спілкування з ним, коли померлого заступає в обрядовій дії його одноліток. Текст замовляння подається формулою імперативу з характерними повторами й відповідною ритмікою переліку дій процедури ритуалу, що є прикладом акціонального корелята вербального тексту з паралелізмом обряду і словесної формули.

Із запобіжних ритуальних дій відзначимо обряд другого (повторного) поховання, поминки за живими, заміна небіжчика його одягом у випадку смерті далеко від дому, включення до поховального обряду весільних елементів аж до прямої інсценізації весілля у випадку смерті неодружених тощо (Микитенко 2010: 98).

Загальне оплакування, без спеціального навчання, є обов'язковим на похованні та кожної неділі після нього протягом поминального періоду, на поминках, наприклад, піврічних, річних чи напередодні календарних церковних 
свят, під час інших поховань. Цікаво, що у ряді поселень (Запланє, Лесковацька Морава) піврічні або річні поминки влаштовують відповідно на шість та дванадцять днів наперед, мотивуючи тим, щоб «покійний встиг на поминальну трапезу». У с. Нижній Стайоваць біля Пчині, а також в інших місцях, узвичаєним $\epsilon$ оплакування надворі, над одягом померлого, що відбувається кожного ранку протягом сорока днів після поховання. Крім того, у Запланє порядок обрядових дій упродовж календарних поминальних днів має характер чітко окреслених традиційно-культурних констант певного магічно-ритуального спрямування, коли значення має кожна дрібниця обрядової дії - час приходу на цвинтар (до сходу сонця), прикрашання могили й хреста, поминальна трапеза - совра, коли страву спочатку мають роздати мертвим «за душу» (да мртви ручају), а також дотримуються регламентації, щоб розподіляла хліб обов'язково та жінка, в якої померла перша дитина (Вукичевић-Закић 1997: 154).

Носіями традиції виступають виключно жінки. Традиція не передбачає найманого оплакування, а також одержання плакальницею винагороди. Оплакування триває протягом усього часу, поки померлий у домі, біля одра, по дорозі на цвинтар, а особливо, коли труну опускають у могилу. Є свідчення щодо оплакування лише «під відкритим небом» - на отвореном простору, послідовно лише вдень. Характерною є поза плакальниці, коли вона оплакує на могилі, - нахилившись і обнявши надмогильний хрест або навколішки й опершись на хрест (у домі також навколішки та опершись на стіл або скриню), схиливши голову на знак скорботи. Обов'язково схилена голова, судячи з народних свідчень, є виразом великої скорботи, але також пов'язується з віруванням у більшу дієвість самого акту звернення до покійного. На цвинтарі можуть оплакувати одночасно кілька жінок - коли одна голосить, до неї підключаються й інші жінки, вони всі разом починають голосити, найчастіше одна за одною, зрідка дві в один голос (Златановић 1999: 105); також разом кожна для себе; в інших випадках - одна закінчує, друга розпочинає свій плач (Fracile 1987: 35). Довше оплакування, як правило, припиняється словами втіхи, якими присутні намагаються розважити плакальницю. Кажуть, що жодна плакальниця не перестає оплакувати сама, зазвичай іiі хтось перерве й допоможе підвестися (Златановић 1999: 105).

Плачів у чоловічому виконанні тут майже не зафіксовано. Водночас, у зоні Хомоле «чоловіки ніколи не оплакують (запевају), а плачуть приховано й тихо, навіть якщо їм дуже тяжко. Лише батько може вголос оплакувати єдиного сина, але коротко: «Ох, синку, що ти зробив з нами!» (Ђорђевић 1938: 186). А проте, є свідчення, що подекуди оплакують і чоловіки (Златановић 1999: 105). У Південній Сербії такий плач зазвичай складається лише 3 «болісних вигуків», напр.: О што ја стар не отидо, него ти!; О Боже, ито ми сина узеде!; Што мене не сабра Господ, него њега!; За тебе ли је, бре синко, тамо!; Сестро, мила сестро, ито нас зацрни! тощо, але від тих, хто має поетичний хист, можна почути й оплакування у віршах. Поодинокі приклади чоловічого оплакування в регіоні фіксуються наприкінці XIX ст., привертають увагу записувачів і пізніше - після Другої світової війни, а також у наш час. Такі тексти ритмізованої прози вимовляються у десяти- або чотирнадцятискладовому вірші з великим зворушенням (наприклад, діти покинули батьківське вогнище, дружина померла, і чоловік залишився сам у гіркій самоті, як «сухе дерево на полонині»; або 
трагічно загинув чотирнадцятилітній онук чи померла старша сестра, яка завжди піклувалася про нього, тощо) і надзвичайно вражають присутніх - здатні «розплакати всіх присутніх», «ніхто не може втримати сльози» (Златановић 1999: 106).

У Хомолє кожна з жінок, що приходила «на плач», мусила оплакати померлого, навіть якщо вона не була його родичкою. Зачувши плачі, і старі і молоді знали, що в селі хтось помер. Плачі (кукање) сповіщали про смерть, якщо вона сталася вдень (Петровић 1948: 300)ํ․ Вночі, як і в інших традиціях, тут не оплакували. Плачі (запевке) тривали досить довго, створюючи враження нескінченних, коли «жінка могла годину оплакувати (нарицати і набрајати), бо серце її від горя було відкрите» (Милосавлевић 1914: 241).

Уже саме повідомлення про смерть могло ставати певним міні-ритуалом. Так, у с. Гружа (південна Шумадія) одна з родичок померлого брала трохи землі 3-під порога, кидала іï на нього, після чого тягла за вуха всіх домашніх, молодших від небіжчика, повідомляючи їм при цьому сумну звістку: «Пішов Н. до баби» (покійної), або «Н. заспокоївся» (Петровић 1948: 292). Характерним $\epsilon$ табуювання лексики, пов'язаної з семантичним полем «смерть» та «померти»: «Благо њему кад се одморио, - звичайно казав хто-небудь із старих про покійного (Мијатовић 1907: 99).

У районі Верхньої Ресави оплакування небіжчика було «дуже поширене». У день поховання померлого оплакують жінки, особливо звичні до цього. Оплакують, як правило, переважно у домі померлого, а також на цвинтарі. Упродовж сорока днів кожного ранку оплакують перед домом померлого (Бошковић-Матић 1962: 192). Заборон щодо виконання плачів найближчими родичками не було зафіксовано.

Змістовий бік плачів зосереджується переважно на вираженні глибокої скорботи і горя родини, друзів та сусідів небіжчика, нерідко навіть згадуються й домашні тварини. Оплакування померлого має виразні ознаки обов'язкового комунікативного акту традиційної обрядової практики. Простими і невимушеними словами жінки намагаються передати фізичні, моральні, психічні якості покійного, вказуючи паралельно на свою самотність, спустошеність і душевний біль через смерть близької людини. Плакальниці переважно описують чесноти померлого, відповідно основною складовою частиною плачів $є$ його уславлення, що досягається, зокрема, широким введенням відповідних атрибутів і метафор: добар, убав, судбина, срећа, тужно извејке тощо (Запланє). Звертаючись до небіжчика з риторичними питаннями (у формі 2-ої особи однини): Joj, брате мој, чујеш ли ме мало?... або Јој, брате мој, је ли те твој Миша спомиғе? тощо, часто просять передати вітання та розповісти про новини тим, що раніше пішли «на той світ».

Плачі сербів у Воєводині, як правило, розпочиналися вигуками jaoj; jay; aj, joj; joj, joj тощо, після чого імпровізується текст, який складається з неоднакових мелодичних частин речитативного характеру, що наслідують спон-

\footnotetext{
${ }^{1}$ Повідомленням про смерть був великий церковний подзвін - тричі, якщо помирав чоловік, двічі, якщо жінка, після чого «тягли» усі звони; про смерть хлопчика повідомляв подзвін (малий дзвін) тричі, дівчинки - двічі (Fracile 1987: 35).
} 
танне усне мовлення. Лише найталановитіші й досвідчені плакальниці здатні при імпровізації витримувати певну ритмо-метричну структуру тексту, що не $€$ тут загальною практикою. Для переважної більшості виконавиць допоміжну функцію виконують вигуки, які дозволяють підготувати виклад наступної частини тексту.

Відповідними рисами характеризується традиція регіону Південної Сербії, зокрема у Запланє, представлена плачами у вільному вірші з неоднаковою довжиною рядка і різного метричного складу. Відсутність стабільної мелодійної і поетико-метричної структури під час виключно одноголосного соло-виконання підкреслює важливість текстового компонента й пріоритет стилю збудженої нарації. Відповідно до цього, а також зважаючи на специфіку обрядового контексту, тужбалиці у Запланє, як і в інших регіонах Сербії, «не вважаються піснями». На відміну від інших жанрів обрядово-звичаєвої сфери кожний тон плачового виразу (в інтервалі переважно квінти) підпорядкований інтонаційній змінності (Вукичевић-Закић 1997: 159-162).

Серед стабільних елементів текстів регіону, представленого характерними для Південної Сербії «інтимно-родинними текстами», що «виражають біль i містять реалії повсякденного життя» (Златановић 1999: 106), найтиповішою є формула, яка пов'язана 3 ініціальними рядками оплакування й полягає у поєднанні ламентативних лексичних одиниць і звертання до небіжчика (напр.: Леле, леле, леле, мајчице!). Така формула може повторюватися у подальшому викладі, зберігаючи при цьому характер особливо наголошених комунікативних моментів тексту. До семантичної парадигми текстової реалізації належать кілька найвагоміших мотивів, серед яких чи не найчастішим є «дорікання», що висловлюється обов'язково у питальній формі (Што сте куће раскућили? Што сте жене оставили? Што сте деиу раселили?). Цей мотив часто доповнюється потенціюванням особистої спустошеності, описом тяжких життєвих обставин (Ја немам одбрану, ја немам договор; Ја сам, другаре, три године сама...). Екскламативні та інтерогативні конструкції відповідають стилю експресивної нарації й визначають стилістичний рівень текстової реалізації, підкреслюючи перевагу вербального компонента порівняно з музичним, а тим самим свідчать про індивідуальність і неповторність кожної окремої інтерпретації. Це, зокрема, підтверджує вислів, що кожна жалостива има свою арију на коју завија, хоча в цілому мелодичне оформлення плачів у Запланє відповідає регіональному музичному діалекту Південно-Східної Сербіі, наявному і в інших обрядових жанрах фольклору, семантична основа яких, за переконанням деяких етномузикознавців, випливає з обрядово-магічної символіки жанру (Вукичевић-Закић 1997: 163).

Про архаїчну структуру плачів сербів у Банаті свідчить їхня музична форма, що звичайно складається лише з однієї мелодичної частини, яка варіюється під час виконання; в деяких випадках перша частина відмінна від інших, і маючи функцію ввідного мелорядка, у тексті більше не повторюється. У мелодичному малюнку виразно відчувається експресивний текстовий акцент, головна ж роль в оплакуванні належить вербальному складникові (імпровізована проза чи вільний вірш).

Поховальний обряд у регіонах Воєводини та Північно-Східної Сербії представлено характерним локальним варіантом, що відзначається певною архаїч- 
ністю синхронного стану традиції, сучасне побутування якої стосовно іншого локального варіанта може розглядатися вже як реконструкція. Ця особливість виявляється також на рівні вербального тексту оплакування. Ще в середині $\mathrm{XX}$ ст. дослідники звертали увагу на те, що плачі румунів та сербів у північно-східній частині Сербії відрізняються не лише формою, але й змістом; «у них яскравіше підкреслюється потойбічне існування» (Петровић 1948: 125). Ці особливості підтверджують і пізніші спостереження, що свідчать про спільні риси плачів сербської та румунської етнічних спільнот регіону (зокрема, вагомою є стилістична роль екскламативних елементів - серб. joj, joj; jao, jao та ін., рум. $j u, h u, h u ; a u, a u, h \hat{\imath}, h \hat{\imath}$ та ін.). Водночас у румунських текстах сильнішим $€$ наративний складник, із структурного боку вони складаються з віршованих восьмискладових рядків (4+4) із парною римою, тоді як у сербських текстах, побудованих за принципом спонтанного мовлення, із нерівномірним фразовим поділом у 5-15 складів, звучать переважно риторичні запитання. Музична форма сербських плачів як така, що складається з однієї музичної частини i варіюється протягом виконання, є давнішою порівняно з румунськими плачами, де переважають більш розвинуті музичні форми, що складаються з 2-3-х частин, які спонтанно комбінуються під час виконання. Цікаво, що записи поховальних плачів, зроблені на території Румунії (м. Олтенія) наводять подібні до сербських текстів структурні характеристики (Fracile 1987: 114), тоді як віршовану форму тексту пісень-плачів - тужбалиць (десяти-, восьмискладовий вірш) представлено переважно у Герцеговині та Чорногорії (Микитенко 1992).

Окремий етнокультурний діалект становить західносербська традиція оплакування, яка має оригінальний і самобутній поетичний потенціал, притаманний регіону, детально розроблений поховально-поминальний обрядовий комплекс, що демонструє своєрідність усіх рівнів обрядової структури виразного соціально-комунікативного спрямування. Функціональне поле поховального оплакування цього регіону, яке має своє продовження у чорногорській традиції, зреалізоване різними формами ритуального плачу - чоловічим плачем лелек, речитативним жіночим оплакуванням кукање, нарицање, плачем, що має допоміжне значення ојкање, срищање, індивідувальним плачем тужење; при цьому кожна форма оплакування більшою чи меншою мірою зумовлена тією чи іншою обрядовою дією. Разом з тим в умовах розвиненої традиції загального (жіночого й чоловічого) оплакування та навчання оплакуванню обрядові й необрядові плачі $є$ взаємопов'язаними й взаємопроникними. Для необрядових плачів немає заборони щодо часу й місця їх виконання; якщо обрядові плачі мають певні заборони («соромно плакати за хазяїном, за чоловіком») та виключення з числа тих, хто оплакує, певних категорій виконавців, то при необрядовому плачі ці обмеження знімаються (Микитенко 2010: 102-103).

Поетична традиція західносербського/чорногорського ареалу, особливістю якої є епіка, виконання епічних пісень у супроводі гусел чи тамбура, а також своєрідний спосіб одно- чи двоголосного співу із сильною вібрацією голосу на складі ој (ојкање, розгање, зерзавање) (Gavazzi 1978: 190-191), значною мірою вплинула на творчий процес виконання плачу як в обрядовому контексті, так і поза ним. У традиційній культурі краю, де «без цих пісень і смерть неможливо собі уявити» (Шаулић 1929: 15), тужбалиці - пісні-плачі стали вия- 
вом етнопоетичної специфіки регіону й характеризуються особливою художньо-поетичною виразністю, емоційно-естетичним спрямуванням та яскравістю патріотичного звучання. Плачі тут складалися в умовах постійної боротьби за національну незалежність, оспівували героїчну загибель на полях битви і мають переважно героїко-епічне забарвлення. Тексти з динарських регіонів Чорногорії та східної частини Герцеговини визначаються як «воєнно-патріархальні» тужбалиці (Златановић 1999: 106). Мотив «уславлення» (кићење) виступає незмінним показником традиції, тоді як багатство художньо-змістового плану текстів дістає пояснення в міжжанрових взаємозв'язках (плачі - епічна поезія) та в «багатошаровості» вербального компонента обряду, коли обрядовий текст дістає своє вираження згідно традиції поетичного висловлювання.

Отже, традиційний обрядовий текст (на змістовому та формальному рівнях) стає релевантним чинником, який враховується при виокремленні певного етнокультурного діалекту та утворює поряд із іншими діалектними (лінгвістичними та екстралінгвістичними) рисами окремий культурно-мовний ареал - у разі чітко окресленої території явищ, а коли йдеться про ареал із «розмитими» контурами - зону, територію із «приблизними» межами (Бородина 2002: 137). Наш матеріал зонального поділу традиційної поховальної обрядовості переконливо свідчить про роль фольклору як чинника певної регіональної та локальної культурної традиції. Ареальні спостереження поховальної обрядовості можуть мати продовження завдяки лінгвогеографічному аналізу лексики, що обслуговує відповідну ритуальну сферу (пор.: Плотникова 2004: 177). Водночас розглянутий матеріал підтверджує традиційне членування південнослов'янського діалектного простору за «меридіональним» принципом із півночі на південь (СД: карта 7), тоді як процеси балканських інновацій пов'язуються із більш наочним протиставленням захід - схід (Плотникова 2004: 252), що у кінцевому рахунку надає нового імпульсу для комплексного міждисциплінарного дослідження народної культури як важливого чинника слов'янської ідентичності.

\section{Використана література}

Бородина, М.А. «Пространство, территория, зона и ареал как лингвогеографические и ареологические термины». Вопросы языкознания 2, 2002: 135-141.

[Borodina, M.A. "Prostranstvo, territoriâ, zona i areal kak lingvogeografičeskie i areologičeskie terminy”. Voprosy âzykoznaniâ 2, 2002: 135-141]

Бошковић-Матић, Милица. „Погребни обичаји“. Гласник етнографског музеја у Београду 25, 1962: 171-194.

[Bošković-Matić, Milica. „Pogrebni običaji“. Glasnik etnografskog muzeja u Beogradu 25, 1962: 171-194]

Вайнрайх, Уриель Языковые контакты. Состояние и проблемы исследования: Пер. с англ. Київ: Вища школа, 1979.

[Vajnrajh, Uriel' Âzykovye kontakty. Sostoânie i problemy issledovaniâ: Per. s angl. Kyïv: Viŝa škola, 1979]

Вукичевић-Закић, Мирјана. „Оплакивање мртвих у Заплању“. [У:] ІУ Међународни симпозијум. Фолклор-музика-дело. Београд: Факултет музичке уметности, 1997, 
$152-184$.

[Vukičević-Zakić, Mirjana. „Oplakivanje mrtvih u Zaplanju“. [U:] IV Međunarodni simpozijum. Folklor-muzika-delo. Beograd: Fakultet muzičke umetnosti 1997, 152-184]

Ђорђевић, Тихомир. „Неколики самртни обичаји у Јужних Словена“. Годишњица Николе Чупића 47, 1938: 153-191.

[Đorđević, Tihomir. „Nekoliki samrtni običaji u Južnih Slovena“. Godišnjica Nikole Čupića 47, 1938: 153-191]

Златановић, Момчило. „Тужбалица у Јужној Србији“. Етно-културолошки зборник за проучавање културе источне Србије и суседних области 5, 1999: 103-107.

[Zlatanović, Momčilo. „Tužbalica u Južnoj Srbiji“. Etno-kulturološki zbornik za proučavanje kulture istočne Srbije i susednih oblasti 5, 1999: 103-107]

Лазаренко, Любов О. Лексична інтерференція в усному румунському мовленні в Україні (лінгвістичний та соціолінгвістичний аспекти). Київ: Букрек, 2001.

[Lazarenko, Lûbov O. Leksyčna ìnterferencîâ v usnomu rumuns'komu movlennì v Ukraïnì (lìngvìstyčnyj ta socìolìngvìstyčnyj aspekty). Kyïv: Bukrek, 2001]

Мијатовић, Стеван. «Обичаји Српског народа из Левча и Темнића». Српски етнографски зборник 7 (1), 1907: 72-100.

[Mijatović, Stevan. „Običaji Srpskog naroda iz Levča i Temnića“. Srpski etnografski zbornik 7 (1), 1907: 72-100]

Микитенко, Оксана О. Сербські голосіння. Поетичний та історико-географічний аналіз. Київ: Наукова думка, 1992.

[Mykytenko, Oksana O. Serbs'ki golosinn'a. Poetychnyı̌ ta istoryko-geografichnyı̌ analiz. Kyïv: Naukova dumka, 1992]

Микитенко, Оксана. Балканослов'янський текст поховального оплакування: прагматика, семантика, етнопоетика. Київ: ІМФЕ ім. М.Т. Рильського НАН України, 2010.

[Mykytenko, Oksana. Balkanoslovians'kyı̌ tekst pokhoval'nogo oplakuvann'a: pragmatyka, semantyka, etnopoetyka. Kyïv: IMFE im. M.T. Ryl's'koho NAN Ukraïny, 2010]

Милосављевић, Сава. „Српски народни обичаји из среза Хомољског“. Српски етнографски зборник 19 (11), 1914.

[Milosavljević, Sava. „Srpski narodni običaji iz sreza Homoljskog“. Srpski etnografski zbornik 19 (11), 1914]

Непоп, Лідія В. Лексичні особливості польських говірок на території Хмельницької та Житомирської областей. Київ: ВПЦ «Київський університет», 2004.

[Nepop, Lidiâ V. Leksychni osoblyvosti pol's'kykh hovirok na terytorï̈ Khmel'nyts'koï ta Zhytomyrs'koï oblasteǐ. Kyïv: VPTS “Kyivs'kyı̌ univetsytet”, 2002]

Петровић, Петар. „Живот и обичаји народни у Гружи“. Српски етнографски зборник 58 (26), 1948: 283-302.

[Petrović, Petar. „Život i običaji narodni u Gruži“. Srpski etnografski zbornik 58 (26), 1948: 283-302]

Плотникова, Анна А. Этнолингвистическая география Южной Славии. Москва: Индрик, 2004.

[Plotnikova, Anna A. Etnolingvisticheskaâ geografiâ IUzhnoĭ Slavii. Moskva: Indrik, 2004]

Радиновић, Сања. „Елементи макроструктуре заплањских обредно-обичајних песа- 
ма у функцији 'зачараног кружног кретања'“. [У:] ІУ Међународни симпозијум: Фолклор - музика - дело. Београд: Факултет музичке уметности, 1997: 442-466. [Radinović, Sanja. „Elementi makrostrukture zaplanjskih obredno-običajnih pesama u funkciji 'začaranog kružnog kretanja'“. [U:] IV Međunarodni simpozijum: Folklor muzika - delo. Beograd: Fakultet muzičke umetnosti, 1997: 442-466]

Семчинський, Станіслав В. Семантична інтерференція мов. Київ: Вища школа, 1974.

[Semčyns'kyj, Stanìslav V. Semantyčna ìnterferenciâ mov. Kyïv: Vyŝa škola, 1974]

СД: Славянские древности: Этнолингвистический словарь (ред. Н. И. Толстой). Т. 1. Москва: «Международные отношения», 1995.

[SD: Slavânskie drevnosti: Etnolingvisticheskiı̌ slovar' (red. N.I. Tolstô̌). T.1. Moskva: "Mezhdunarodnye otnosheniâ", 1995]

Толстой, Никита И. Язык и народная культура: Очерки по славянской мифологии и этнолингвистике. Москва: Индрик, 1995.

[Tolstő̆, Nikita I. IAzyk i narodnaâ kul’tura : Ocherki po slavânskoř mifologii i etnolingvistike. Moskva: Indruk, 1995]

Трубачев, Олег Н. Этногенез и культура древнейших славян: Лингвистические исследования. Москва, 2003.

[Trubachev, Oleg N. Etnogenez i kul'tura drevneĭshikh slavân: Lingvisticheskie issledovaniâ. Moskva: 2003]

Шаулић, Новица. „Предговор“. [У:] Српске народне тужбалице. Београд: Графички институт „Народна мисао“ I, 1, 1929: 7-30.

[Šaulić, Novica. "Predgovor". [U:] Srpske narodne tužbalice. Beograd: Grafički institut "Narodna misao" I, 1, 1929: 7-30]

Fracile, Niko. Vokalni muzički folklor Srba i Rumuna u Vojvodini: komparativna proučavanja. Novi Sad: Matica Srpska, 1987.

Gavazzi, Milovan. Vrela i sudbine narodnih tradicija: Kroz prostore, vremena i ljude. Zagreb: Matica Hrvatska, 1978.

Jensen, Moller, Erik Ingeog. En deskriptiv belysning af det tyske mindretal i Nordslesvig 1945-1970. Kobenhavns Universitet, 1974.

Thomassen, Bjorn. "Border studies in Europe: Symbolic and political boundaries, anthropological perspectives". Europea II-1, 1996: 37-48.

Vereni, Piero. "Boundaries, persons, individuals: Questioning 'identity' at national borders”. Europea II-1, 1996: 77-89. 


\title{
Оксана Микитенко
}

\section{ПОГРЕБНЕ ТУЖБАЛИЦЕ У ИНТЕРФЕРЕНТНИМ ЗОНАМА СРБИЈЕ: О ПРОБЛЕМУ ГРАНИЧНЕ ЕТНОКУЛТУРЕ}

\begin{abstract}
Резиме
Проблем језичког и културног мешања веома је релевантан - њему се посвећује пуно пажње у лингвистичким, етнокултурним, фолклористичким истраживањима. Термин језичка интерференција у научна разматрања увео је В. Вајнрајх а користе га етнолози и фолклористи за означавање различитих врста етнокултурне интеракције које могу утицати на обе контактне културе. Проучавање етнокултурног дијалекта један је од приоритетних задатака савремене етнолингвистике, истовремено се методе етнолингвистике све активније укључују у фолклористичку анализу. На територији Јужне Славије, дијалект етнокултурног простора и традицијске културе представља низ могућности у различитим регионима, укључујући ту и Србију. Етничка мозаичност јужнословенског региона, где дистантних појава готово да и нема, огледа се у традицији посмртне жалости. Војводина и североисточна Србија истичу се као архаичне зоне појаса старобалканске културе са прилично одређеним мешањем словенске и романске језичке и фолклорно-етнографске културе, где је оплакивање мртвих уско повезано са општом традицијом духовне културе дугог певања, подређеног функционалној ритуалној доминацији. Погребни обред у регионима Војводине и североисточне Србије представљен је карактеристичном локалном варијантом коју обележава одређена архаичност синхроног стања традиције. Опште типолошке одлике жанра са одређеним одликама локалне музике и фолклорног дијалекта забележене су у југоисточном региону Србије, посебно у локалном подручју Заплања између Ниша, Власотинца и Беле Паланке, које је дефинисано као одвојени музички и фолклорни идиом. Одвојени етнокултурни дијалекат је западносрпска традиција оплакивања која има оригиналан и препознатљив песнички потенцијал својствен региону, детаљан погребни и меморијални ритуални комплекс који демонстрира јединственост свих нивоа ритуалне структуре изражајне социјалне и комуникативне оријентације. Функционално поље погребног оплакивања овог краја, које има свој наставак у црногорској традицији, остварује се разним облицима обредног оплакивања. Преглед зонске поделе традиционалних погребних обреда убедљиво показује улогу фолклора као чиниоца одређене регионалне и локалне културне традиције, што на крају даје нови замах свеобухватном интердисциплинарном проучавању народне културе као важног фактора словенског идентитета.
\end{abstract}

Кључне речи: Србија, погребни текст, зона интерференције, фолклор, етнокултурни контакти. 